Tapscott, C. \& Thompson, L. (2013). Between supply and demand: the limits to participatory development in South Africa. International Review of Administrative Sciences,

\title{
Between supply and demand: the limits to participatory development in South Africa
}

\author{
Chris Tapscott and Lisa Thompson
}

\begin{abstract}
Much of the focus in the literature on participatory development has been on the demand side and on the extent to which citizens succeed in pressuring the state to deliver basic services. Less attention has been focused on the supply side of participatory development, namely on how state institutions give effect to development policies. PostApartheid South Africa is replete with policies and legislation supporting participatory processes and yet in practice this has seldom lived up to the ideals espoused. This article examines the delivery of public housing in poor communities in three municipalities in South Africa and argues that there is a mismatch between how the formulators of policy understand participation and how it is interpreted by beneficiary communities and local officials. It concludes that considerably more attention needs to be focused on why officials fail to translate national policies into action if participatory democracy is to attain any legitimacy in the population at large.
\end{abstract}

\section{Points for practitioners}

Effective citizen engagement in decision-making processes is the key factor in participatory development programmes. Enabling legislation and policy is essential to the process but it is not sufficient to ensure participation. The design of participatory programmes will thus need to take into account the capacity of communities to organize themselves and will need to factor in the means and time to develop their ability to engage effectively. Officials managing participatory development projects need to undergo formal training so that they understand that the manner in which beneficiaries participate is as important the actual activities in which they are involved.

\section{Introduction}

The concept of participatory development, albeit propagated under different labels, has a long history stretching back to the notions of self-rule and self-reliance advanced by colonial administrations in the 1940s and 1950s (Cooke, 2003). Although there were various attempts to popularize the idea of participation in the intervening years, the concept was only brought into the mainstream of developing thinking from the 1980s onwards as part of a neo-liberalist paradigm (Hickey and Mohan, 2004). The approach which, inter alia, envisaged a diminution of the state and strengthening the role of civil society was seen both as a means to empower ordinary citizens, and the poor in particular, and to promote more sustainable forms of development (Jennings, 2000). 
According to a World Bank resource book, 'Participation is a process through which stakeholders influence and share control over development initiatives and the decisions and resources which affect them' (World Bank, 1998: 3). In this formulation, participatory development was seen to be inherently good in the potential it held to empower local communities and to promote greater efficiency and effectiveness in the delivery of development programmes; for its advocates, furthermore, its virtues were perceived to be self-evident and incontestable. Despite the fact that participation was conceptually vague and ill-defined (Kapoor, 2002; Lavigne Delville et al., 2005) and meant different things to different people, it was championed in certain political and academic circles (Burkey, 1993; Chambers, 1995) and was rapidly absorbed into the orthodoxy of the development discourse espoused by multi-lateral and bilateral funding agencies (OECD, 1997; UNDP, 1995; World Bank, 1998).

However at the turn of the twenty-first century, a wave of revisionist writers severely criticized the concept on the grounds that it reduced the complex processes involved in poverty alleviation to a series of participatory methods and techniques which, once mastered, would facilitate efficient and sustainable patterns of development (Cooke and Kothari, 2001; Goebbel, 1998). They also argued that the proponents of participatory government naively under-estimated the impacts of local power relations and the fact that the poorest of the poor were seldom the primary beneficiaries of participatory programmes which were frequently subject to capture by local elites (Platteau and Abraham, 2002). In that respect, Cleaver went so far as to state that 'there is little evidence of the long-term effectiveness of participation in materially improving the conditions of the most vulnerable people or as a strategy for change' (Cleaver, 2001: 36).

In defence of participation, subsequent writers have conceded that the attempts to depoliticize participatory development were ill-conceived, but they have argued that there remains considerable merit in involving communities in the planning and management of development initiatives. The process, according to Cornwall and Gaventa, involves 'a shift in thinking from seeing people as "users" to a broader recognition of their rights and agency - including rights to information and to involvement in decision-making over issues with implications for resources' (Cornwall and Gaventa, 2001: 11). Beyond a simply tokenistic involvement of citizens in peripheral decisions, they argue, recognizing them as agents requires far-reaching changes in the way in which community participation is currently envisaged.

In recognizing the political dimensions of development, the proponents of this approach have aligned the concept with the notion of participatory democracy which focuses, in the first instance, on the attainment of basic human rights (Gaventa, 2004). Over the last two decades academic research has focused on the interplay between the realization of basic, or first-order, rights and socioeconomic rights and entitlements as these are articulated as part of development policies in newly democratizing states (Mehta et al., 2010). Much of the writing in this vein has looked at the ways in which citizens have mobilized to extract concessions from the state, and indeed there is consensus that mobilization in developing contexts is rather more frequently about socioeconomic rights, although these often bring into question basic rights when demanded or contested by 
poor communities (Thompson and Tapscott, 2010). Research on community activism and participation has tended to look at the demand side of participatory democracy (that is on how citizens struggle to actualize their socioeconomic rights) and, by implication, the demand side of participatory development. While such work has provided valuable insights into the transformatory possibilities of participation, it has paid relatively little attention to the supply side of participatory development, that is on how or if the state, and particularly the local state, is able to give effect to the precepts of participation even when this forms part of official policy.

The discussion which follows looks at efforts to implement a policy of participatory housing delivery in post-Apartheid South Africa and argues that even in contexts where there is a political commitment to such a process, the engagement of citizens, and particularly of poor citizens, is considerably more challenging, from an administrative perspective, than policy makers might ever have envisaged. Over and above the vested interests of local elites, the vested interests of ordinary citizens, desperate for housing, pose additional challenges in identifying eligible candidates for state-sponsored housing projects. This is because their involvement in a housing project is generally driven less by a desire to benefit the collective community than an individualistic pursuit to capture resources provided by the state (Be' nit, 2002: 63; Emmet, 2000: 505). The extent to which different communities are able to mobilize and organize themselves to engage with the state, furthermore, is shaped by their different historical trajectories, social cohesion, and socioeconomic standing. Relatedly, the difficulty of inter-governmental coordination in interpreting policy between different levels of government together with limited administrative capacity has generally reduced the process to a bureaucratic exercise devoid of content for the intended beneficiaries. Alternatively, the process of participation is often so protracted that citizens lose interest and faith in the idea of participation in its entirety and resort to protest action. ${ }^{1}$ Under these circumstances there appears to be a mismatch between the demand side of participatory housing delivery, what citizens expect, and the supply side, the policies and practices in place to ensure this delivery.

The investigation looks at the attempts to implement a policy of participatory housing in three municipalities in the Western Cape Province of South Africa. In so doing, it considers the challenges faced by local authorities in delivering public housing in a participatory manner. These challenges relate to the design of participatory models (which fail to take into account the extent to which communities are able to mobilize towards a common goal), to the demands of citizens, and to the commitment of municipal officials to the process of participation. As a point of departure, it is necessary to provide a brief overview of the form of the state and the policy framework which informs participatory development and the delivery of public housing in South Africa.

\section{The legislative and policy framework for participatory housing delivery}

Following the demise of white minority rule and the advent of democracy in 1994, the South African state was extensively reconfigured. Although retaining a three-tier system of government, based on national, provincial and local government, considerably more power was devolved to the nine provinces and 283 municipalities than in the past. However, as a number of provinces and a large proportion of municipalities were newly established in

\section{https://repository.uwc.ac.za/}


this process, their capacity is highly variable in terms of both infrastructure and personnel. Further challenges exist in managing the concurrent responsibilities assumed by the different levels of government (Tapscott, 2000). This state of affairs has placed considerable pressure on the state, and particularly the local state, to deliver services to a citizenry with high expectations of both a greater say in decision-making and of substantively improved livelihoods.

By its very nature, Apartheid rule represented the antithesis of participatory governance, and its racist and authoritarian mode of administration implied that the majority of South Africans had little or no say over policies which affected their daily lives. Thus, it is perhaps not surprising that the incoming African National Congress (ANC) government, having swept into office on the tide of popular resistance in April 1994, should have brought the notion of participation into the mainstream of political thought and raised it to a first principle of government policy. This is evident in the 1996 Constitution, which stipulates that '(p)eoples' needs must be responded to and the public must be encouraged to participate in policy making' (Republic of South Africa, 1996: sections 195 (1)e). The Constitution also stipulates that national legislation must ensure that these values and principles are promoted. To that end, a plethora of legislation has been enacted which explicitly charges different state structures with responsibility for the promotion of citizens' participation. Thus the 1997 White Paper on Transforming Public Service Delivery aimed to establish a framework for the delivery of public services which entailed listening to the views of citizens 'and taking account of them in making decisions about what services should be provided ... (as well as) treating them with consideration and respect' (Department of Public Service and Administration, 1997: section 1.3.3). Building on this theme, the 1998 White Paper on Local Government stressed the need for local governments to 'adopt inclusive approaches to fostering community participation, including strategies aimed at removing obstacles to, and actively encouraging, the participation of marginalized groups in the local community' (Department of Constitutional Development, 1998: section 1.3).

The commitment to community participation was carried forward into the delivery of public housing. Recognizing the adverse impact of Apartheid on the settlement of the majority of South African citizens and mindful of the massive shortfall of urban accommodation, the incoming democratic government, from the outset, placed emphasis on the provision of housing as a basic human right. Thus the 1994 Housing White Paper asserted that the government was 'under a duty to take steps and create conditions which will lead to an effective right to housing for all ... It is held that a person has a right to live in dignity, in habitable circumstances. Government therefore will vigorously promote an effective right to housing for all, within the resource and other limitations applicable to it' (Department of Housing, 1994: section 4.4.2). The principles enunciated in the White Paper were given legal effect by the 1996 Constitution. Enshrined in the Constitution's Bill of Rights is the declaration that '(e)veryone has the right to have access to adequate housing' and furthermore that the 'state must take reasonable legislative and other measures within its available resources, to achieve the progressive realisation of this right' (Republic of South Africa, 1996: section 26). Ensuing from this edict, a new National Housing Act was promulgated in 1997, committing the state, inter alia, to prioritize the needs of the poor in the design and delivery of housing development programmes.

\section{https://repository.uwc.ac.za/}


The 1997 National Housing Act asserts that national, provincial and local spheres of government must give priority to the needs of the poor and must consult meaningfully with individuals and communities affected by housing development. The Act also dictates that the delivery of housing must be administered in a transparent and equitable manner (Republic of South Africa, 1997: section 2(1)). The currency of the Government's commitment to consultation, public participation and transparency is further evident in the 2008 Social Housing Act which emphasizes the need to 'consult with interested individuals, communities and financial institutions in all phases of social housing development'. It also prescribes 'the involvement of residents and key stakeholders through consultation, information sharing, education, training and skills transfer' (Republic of South Africa, 2008: section 4.4.4).

However, while various legislative instruments and policy papers provide an enabling framework for the delivery of public housing, they do not specify precisely how this is to be achieved by the different tiers of government. In the terms of the Constitution, as indicated, the delivery of housing is a concurrent responsibility of all three spheres of government. Following this model, the 1997 Housing Act assigns responsibility to the national government to determine provincial policy in respect of housing development. Thereafter, provincial governments must assume responsibility for promulgating legislation to ensure effective housing delivery and must support and strengthen the capacity of municipalities to effectively deliver public housing. In the final instance, municipalities are charged with the responsibility of ensuring that housing is delivered within the policy framework. However, generally across all sectors, the alignment of policy between different levels of government has proven to be a major challenge to the democratic state since its inception and this applies no less to the delivery of housing (Tapscott, 2000; Thompson and Nleya, 2010).

The 2009 National Housing Code, prepared by the national Department of Human Settlements (formerly known as the Department of Housing), provides an outline of the measures to be followed in implementing the National Housing Act. The Code reemphasizes the need for the delivery of public housing to be 'participatory and decentralised allowing effective response to priorities and opportunities at the local level and enabling all role players to contribute their skills, labour, creativity, financial and other resources to the housing process' (Department of Human Settlements, 2009: section 2.4.1). However, while national policy is explicit in its intent to advance community participation in local-level decision-making and particularly in the delivery of basic services, the administrative practicalities of doing so, the supply side, have seldom been made explicit. Still less attention has been given to the manner in which authorities should engage with large numbers of poor households in ways which are perceived to be transparent and legitimate. Finally, the drafters of policy gave little consideration to the widely differing levels of administrative capacity extant in municipalities across the country. Thus, while some larger municipalities have the resources to engage with communities in a fairly meaningful fashion, others appear to be going through the motions, ensuring minimum levels of compliance with legislation and policy but without evidence of substantive participation by local communities. 
The case study which follows discusses the attempts to advance a policy of beneficiary participation in public housing allocation in ten projects in three municipalities in the Province of the Western Cape, namely metropolitan Cape Town, Drakenstein and George. ${ }^{2}$ The municipalities were selected to reflect the experiences of large, medium and small municipalities in the delivery of public housing and to examine the ways in which national housing policy is differentially reflected at provincial and particularly at local implementation levels. Information derived from the ten projects has been aggregated into a single case which is discussed below.

\section{Themobilization of communities and establishment ofbeneficiary committees}

In delivering public housing projects and in giving effect to the prescripts of national policy, a municipality is obligated to work with the representatives of targeted communities through what are called 'beneficiary committees'. The beneficiary committees are understood to be elected by community members who are to be the recipients of public housing. In implementing participatory development, furthermore, municipalities are obliged by the Housing Code to draw up a structured agreement (also referred to as a 'social compact') with a beneficiary committee prior to the roll-out of a housing project (Department of Human Settlements, 2009: Part 3, section 3.9: 30). While the drawing up of a social compact between a beneficiary committee and a municipality appears, at face value, to be a logical step in establishing a basis for community participation, the process is considerably more complex than its designers might have imagined. This is because the different types of housing projects developed by municipalities present different challenges in both identifying the most appropriate community-based partners and in selecting eligible beneficiaries in a fair and transparent manner. As will be discussed, the challenges in determining criteria for the selection of beneficiaries for an entirely new housing project, a greenfield initiative, will differ from those in the in situ upgrading of an informal settlement.

In preparing a project for provincial government approval and funding, the Housing Code specifies that a municipality must submit a copy of a social compact which reflects the agreement of beneficiary groups and other stakeholders in the community on a number of mutually identified key issues relating to the project. Among the issues to be considered are the following: the housing needs of the relevant community; the extent to which the housing project will meet the housing needs of an identified target market with particular reference to the appropriateness of the location, the number and type of residences to be constructed, the finish of the dwellings, the full cost to the beneficiary, and the level of services to be provided (Department of Human Settlements, 2009: Part 3, section F: 45).

As the determination of norms and standards, in terms of the Housing Act, is the responsibility of provincial governments, the Code does not provide specific details on how the social compacts, should be drawn up. In other words, the framework for determining who should represent communities in drawing up social compacts, the content of the agreement and the expected roles of those involved is left to provincial governments to decide. In the Western Cape both provincial and local government officials who were interviewed reported that the provincial government had left responsibility to the municipalities to either draw up or delegate the drawing up of the compact to a contracted project developer. ${ }^{3}$ As a consequence, the interpretation and 
implementation of participatory policies is left to the differential capacities of local housing officials.

\section{Theselection of beneficiaries and appointmentofbeneficiary committees}

In terms of the Housing Code, as indicated, a municipality is expected to establish ways both to identify beneficiaries and to select a representative beneficiary committee. As there are different policy issues to be addressed in delivering public housing to poor households (those who fall below a monthly income of R3500, roughly US\$450), allocation schemes cannot perforce draw on one set of selection criteria. In the format envisaged in the policy, the beneficiary committees (as the legitimate representatives of a community) should assist municipalities in the selection of beneficiaries for a given project. However, in a context where there is huge demand for housing, such an arrangement was never entertained by any of the municipalities researched. This is because municipalities are expected to balance the demands of those on housing waiting lists with the often dire needs of vulnerable households (the disabled, aged, etc.) or those living in hazardous circumstances (such as on swampy ground or next to unguarded railway lines).

These source area splits entail value judgements in the selection of beneficiaries which are often politically laden. While it has been possible to involve beneficiaries in the allocation process in a limited number of projects (for example, in selecting households to be moved in an in situ upgrading project), their input in selecting households for a greenfield project, which draws potential beneficiaries from an entire municipality, as intimated, has proven to be problematic. It is evident from interviews with officials in all three municipalities that they fear that the vested interests and, as shall be seen, the sometimes questionable legitimacy, of beneficiary committee members, who are themselves generally seeking houses, would be such that they would override attempts to establish objective selection criteria. As a consequence, municipalities have made use of the waiting lists (selecting those waiting longest and who pass a means test) and have also reserved a proportion of houses for the severely disadvantaged (on criteria which have been determined by municipal councils).

From the above it is clear that the actual selection of beneficiaries is largely completed before the setting up of beneficiary committees (although practice differs from project to project) and these bodies do not have a direct say in selecting who is to receive housing. In some cases, as occurred for example in Project 59 in the Drakenstein municipality, a community did aggressively, and effectively, pressure the local authority to effect a different system of allocation. This occurred when the residents of two informal settlements (Fairylands and Siyahlala) resorted to protest marches to compel the municipality to change the formal allocation from an 80:20 split between the waiting list and council tenants to a 50:50 split between the two informal settlements. ${ }^{4}$ This form of engagement, however, proved to be the exception rather than the rule and indicates that to be heard, the community had to exercise their rights outside of the formally constituted channels for communication with the municipality. It also does not constitute an example of best practice as the municipality, rather than adhering to a broader and more inclusive process of participation, deviated from its allocation policy under pressure from specific interest groups. 
It was evident from interviews across all three municipalities that participation by the community as a whole is restricted to attendance at a public meeting at which beneficiaries (selected by the municipality) are invited to elect a beneficiary committee. Once the beneficiary committee has been elected, its role is to liaise with the community. In most cases the beneficiary representatives will also liaise with the project developer about the types of house to be built as well the choice of possible finishes. In general, however, they exercise no oversight role when it comes to the construction of housing units and they serve mostly as a medium of communication between the municipality, the developer and the community. In addition, municipalities typically establish Project Steering Committees (PSCs) as the key deliberative body on a housing project, and these comprise representatives from local government, local councillors, representatives of the housing developer (where one has been appointed), together with representatives from the beneficiary committees. The beneficiary representatives consequently have a minority voice in the PSCs which, in any event, generally deal with the technical details of the construction process.

\section{The limits to community mobilization}

Perhaps one of the greatest weaknesses of the current system of participatory housing is the broad assumption that there is a level of homogeneity in the way that different communities, with widely different historical trajectories, are able to mobilize towards a common purpose. Apartheid rule, in its intent and practice, served to divide and rule according to race, ethnicity, socioeconomic status and place of birth (black people born in the rural areas were consigned to live there). The histories of social mobilization both against Apartheid rule and for access to services denied them consequently differs significantly from community to community. In some communities, such as those of African people who migrated in from the rural areas some 20 years ago and who now reside in the sprawling informal settlement of Khayelitsha on the margins of metropolitan Cape Town, there is a strong tradition of community organization and residents are accustomed to electing representatives to street committees, ward committees and the like. ${ }^{5}$ Through these organizations, furthermore, community leaders are better known to residents and their standing appears to be respected. In this context, there are regular report back meetings and greater trust of the decisions made on their behalf by the beneficiary committees (Thompson and Nleya, 2010).

In communities which have been relatively recently formed or which include long-settled residents together with others who have been more recently re-settled in the area, the establishment of coherent beneficiary committees is problematic. Thus, in the case of Drommedaris and Bardale in Cape Town, which are emergency settlement projects, residents, although of the same ethnicity, are drawn from different geographical locations. In both settlements the beneficiary committees are divided and meet separately in their own communities, and sometimes separately with the municipal authorities, even though they are encouraged to form one entity. ${ }^{6}$ In this context, the feedback to communities is somewhat erratic and it is often left to municipal officials to provide details on the housing projects.

In communities such as Belhar, another Cape Town settlement, where there has been little or no history of social mobilization, beneficiary committees have struggled to gain 
legitimacy. This is because those appointed as representatives often have no standing in the community and have been elected by acclamation on the basis of a nomination at the first public meeting of beneficiaries. Lacking a formal mandate from the community (and hence an obligation to take their position seriously), these representatives participate erratically in beneficiary committee meetings and many drop out entirely. It is also evident that their feedback to their constituencies is limited or non-existent. ${ }^{7}$

The legitimacy of beneficiary committees is also influenced by the type of housing project which they are expected to represent. In the case of in situ upgrading schemes, where housing is constructed for an entire community, beneficiaries are more likely to know the individuals whom they elect to a committee. They are also more likely to accept the decisions reached by their representatives on the project steering committee. In projects which recruit people living close to a new housing development, the process is not as straightforward but the prospect exists for some form of locality, if not community, identity which will facilitate the election of a beneficiary committee which is accepted as legitimate by the community. In the case of greenfield projects, as indicated, the process of electing a representative beneficiary committee is especially challenging. This is because beneficiaries are not known to each other, they have no history of collaboration and trust levels between them are low. ${ }^{8}$

There is also some evidence to show that community leadership can be patriarchal in its orientation and exclude women from participatory processes. In the case of Drakenstein's Project 59, Phase 7, the community leaders decided on a 'meeting of the men' with the municipality because, as one of the male beneficiary representatives informants stated, 'women are noisy and disruptive, they don't know what they want'. While the women representatives in the focus group meeting disagreed with him, they were unwilling to elaborate their concerns past mentioning that the needs of vulnerable groups and other community needs (such as the location of crèches) had not been prioritized in the allocation of houses as they would have wished. ${ }^{9}$

A further factor undermining the legitimacy of beneficiary committees has been their relation to PSCs. In cases where a beneficiary committee has been conflated with a PSC or is effectively incorporated into one, beneficiary committees appear to serve little purpose and they are largely ignored by beneficiary communities. This is because they are seen as merely the conduits for decisions taken by the PSC and, by inference, the municipality.

The appointment of Community Liaison Officers (CLOs) by the project devel- opers as intermediaries is a further factor which undermines the legitimacy of beneficiary committees. Not only are these CLOs paid for their services (a source of contention in that they are sometimes also beneficiaries themselves), but they have the time to interact with beneficiary communities in ways which beneficiary committee members do not. In such circumstances, both municipal officials and the developers frequently bypass beneficiary committee members in their dealings with the community and, in the process, diminish their standing in the public eye. ${ }^{10}$ Where beneficiary committees are seen by their communities to be largely powerless in their dealings with officials and when they have little to show for their engagement with PSCs, their legitimacy is likely to be limited. A lack of trust in beneficiary representatives, as intimated, is likely to lower trust in the entire 
process of beneficiary selection, the relocation of households, etc. Conversely, where there is a legitimate and active beneficiary committee in place, there is greater acceptance of the legitimacy of the housing allocation process. The uneven and place-specific capacity of communities to mobilize and coordinate their activities thus plays a pivotal role in the manner in which they 'interpret, interface with and access state-run urban reconstruction projects such as housing provision' (Oldfield, 2000: 859).

\section{The limits to voluntarism}

The functioning of the beneficiary committees also points to the limitations of voluntarism in supporting the process of participation. Municipal officials expressed their disappointment that many beneficiary committees only lasted until such time as their members had received houses, following which they dissolved. As a consequence, there was insufficient community input in subsequent phases of a housing project, including the construction of clinics, crèches and other public facilities. This state of affairs is unsurprising, however, because of the ten projects examined, the average time period between selection and delivery of houses was a minimum of three years and in some cases as long as five to seven years. ${ }^{11}$ Delays of this duration place beneficiary representatives in an untenable position and in many cases ensure that they are not willing to volunteer for future leadership roles. As one former member of a beneficiary committee in Drakenstein stated, 'when we have our houses we need money for them and our families, we don't want to spend more time on this (lobbying the municipality)'. ${ }^{12}$

In focus group and individual interviews with beneficiary committee members it was evident that their role as community representatives and as members of the PSC is a largely thankless one. They are not compensated for their time or effort in liaising with the communities they are elected to serve, and have to rely heavily on the municipality to be able to communicate with their constituencies on issues discussed in the PSC. It is also clear that in most cases they are the bearers of bad news, having to communicate endless time delays in the delivery of housing. They also have to mediate in the difficult task of deciding who does not get houses (for example, where it is not possible to accommodate all households in an informal settlement upgrading project). Lacking any training in the process, most of the beneficiary representatives felt they did not have sufficient knowledge or understanding of the allocation process from selection to the completion of the project, as information appeared to be conveyed to them on a need-to-know basis.

\section{Thelimits of official understanding of participation}

The election of a representative committee in a community that has no history of social mobilization or sense of common identity, as indicated, is likely to be challenging under the best of circumstances. In contexts where officials and communities lack an understanding of the intent of participation, however, the outcome is likely to be a bureaucratic exercise conducted under sufferance. Where community participation is not understood by officials to have any intrinsic value, they will quickly interpret it in narrow instrumental terms. While the intent of legislation and policy, and indeed of senior officials in government, might well be to engage civil society more actively in development processes, this view is frequently not understood or shared by lower-level bureaucrats particularly at the municipal level. As Manor explains, 'Low-level bureaucrats see a more assertive civil society as a threat to their autonomy. They therefore often seek to curtail the influence of voluntary 
associations and user committees by employing methods that co-opt these committees so that their control of development processes survives' (Manor, 2004: 204). In the case study it was evident that the understandings of lower-level municipal bureaucrats of the role of beneficiary committees differed from those held at other tiers of government. Most viewed these structures largely as vehicles for the transmission of information (and decisions) about a housing project to beneficiary communities. The project developers, likewise, viewed the committees largely in instrumental terms as assisting in the roll-out of the housing project, after beneficiaries had been selected by the municipality concerned. As a consultant to one project put it, beneficiary committees were expected to be the 'eyes and ears of the municipality on the ground' with the assigned task to ensure that a project is implemented smoothly. ${ }^{13}$

Pressures to roll out housing programmes are such that officials and the developers they have contracted frequently simplify complex social processes and pursue shortcuts in their attempts to mobilize communities. These shortcuts might entail attempts to co-opt community representatives (by selecting those that are likely to be most compliant), to limit their role in decision-making processes (for example, by ensuring that they have a minority vote on project steering committees), or to side-step them entirely in their dealings with beneficiary communities (by making use of CLOs). As Cleaver points out, from the perspective of housing developers and the officials who commission them, there is an inherent difficulty in incorporating project concerns with participatory discourses. For those implementing a project, it is by definition, a clearly defined set of activities, concerned with quantifiable costs and benefits, with time-limited activities and budgets. The project imperative emphasizes meeting practical rather than strategic needs, instrumentality rather than empowerment' (Cleaver, 1999: 598).

A lack of official understanding of the process of participation was also evident in the approach adopted by municipal officials in the drafting of social compacts with community representatives. All three municipalities had drawn up templates for social compacts but these were generic documents which provide little scope for real community engagement on the terms of the agreement. This lack of appreciation of the objectives of participation is evident in the actual design of the compacts which provide little space for addenda or other inputs from the beneficiary committees. In other words, beneficiary committees are expected to sign off an agreement predetermined by the municipality. In all three municipalities the social compacts were in English despite the fact that the vast majority of the inhabitants were Afrikaans or Xhosa speaking with relatively low levels of education. ${ }^{14}$ A project developer interviewed on this issue stated that the social compacts were a waste of time because the beneficiary committees understood neither their content nor their purpose. ${ }^{15}$

The net effect of this state of affairs is that the signing of a social compact is largely a bureaucratic paper exercise which is presented to beneficiaries as a necessary step to secure the release of funds from the provincial government for commencement of a project. It also does not appear as if the compacts are subject to any review or scrutiny by the Provincial Department of Local Government and Housing once they are received. As a consequence, social compacts cannot be considered living documents in any sense of the 
word and it would appear that neither municipal officials nor beneficiaries considered them to be of any significance in ensuring accountability on the part of either party.

\section{Conclusion}

This research on participation in public housing development in the Western Cape Province of South Africa illustrates the disjuncture that can occur between the supply and demand sides of participatory development. The demand for housing as a basic right of citizenship is, as indicated, high and manifests itself in frequent public protest by the poor against the state's failure to deliver houses. The state's commitment to supply public housing in a participatory way, likewise, is evident, at least formalistically, in an array of policies and legislative measures. Notwithstanding the latent potential for a convergence of these forces of supply and demand, it is clear that the practice of participatory development remains some distance from the ideals enunciated in policy instruments. In particular, it is apparent that the aspirations of policy formulators exceed both the administrative capacity of municipal officials and the potential of communities to mobilize.

From the supply side, over and above the challenges of inter-governmental coordination, it is evident that there were differing understandings of the meaning and intent of participatory processes among different role players. For most municipal officials and developers, beneficiary participation was viewed as a means to an end (the expeditious delivery of houses) rather than as a simultaneous process of promoting a community's capacity to influence the manner in which state services are delivered (Lemanski, 2008: 395). In this context, the involvement of communities was frequently seen to be a timeconsuming and frustrating process which they sought to circumvent wherever possible. Even in terms of the limited role assigned to beneficiary committees in implementation, the situation was aggravated by the fact that information and power asymmetries exist between municipal officials and community members. Communities are frequently unaware of their entitlements and of the options available to them, for example, in the construction of different housing types. The notion of a partnership between state and community thus remains purely rhetorical, and although the social compacts are intended to commit both parties to fulfil certain obligations, in practice there is little recourse on the part of either if there is a failure of compliance. For communities, in particular, delays by municipalities in the roll-out of housing represent an egregious breach of contract and yet they are powerless to hold them to account.

The presumption by officials that all communities in a municipality are equally capable of organizing themselves towards a common cause and that there is a tradition of voluntarism sufficient within them to sustain this is illustrative of a superficial grasp (or a disinterest) in the complex social dynamics that make up all communities irrespective of their socioeconomic character. Yet, the findings of this research confirm the view advanced by da Cunha and Pena that participation 'works for groups that are already able to help themselves .. .' and furthermore, that it works well 'only when the institutions of participation are in place before the need they address arises and when the institutions are compatible with its objectives' (Da Cunha and Pena, 1997: 20).

While the research conducted for this article suggests that participatory development in the delivery of housing in the Western Cape Province is a work in progress, it is also 
evident that the supply side of the approach has potential provided there is more realism about its prospects and the manner in which it is pursued. From the perspective of inter-governmental relations, it is important that provincial governments recognize the varied capacity of municipalities under their aegis and address these asymmetries by setting down norms and standards for the selection of beneficiaries in different housing project types and for interaction with beneficiary committees. In that respect, it is also important that municipal officials recognize the limits of voluntarism and provide a small stipend to members of beneficiary committees and, at the same time, provide them with the training necessary to carry out their roles effectively.

It is also essential that municipal officials managing housing projects undergo formal training so that they understand participatory development as both product and process. In other words, it is understood that the way in which beneficiaries participate is as important for the success of public housing programmes as the actual construction of dwellings. Implicit in such an exercise is the need for municipal officials to understand that citizen participation constitutes a basic democratic right, embedded in the constitution and in a succession of legislative and policy instruments, and that the state is beholden to make this process meaningful.

The importance of factoring in the time and resource costs of participation will also need to be instilled into official thinking and included in the tender specifications set out for housing developers. In other words, the time necessary to interact with communities and beneficiary committees will need to be included in project schedules and must be costed accordingly. At the same time, it is important for municipalities to ensure that housing is delivered on time, as this will assist in retaining community interest in the process of participation. It is also evident that there is a need for a clear specification of the criteria used in the selection of beneficiaries and for these criteria to be communicated widely (by means of public meetings, posters, the media and radio in particular) to communities that might include potential beneficiaries. Effective communication will also help in managing unrealistic demands by poor communities who often have no knowledge of the criteria applied by a municipality in selecting beneficiaries.

It is also clear that some assessment of the organizational capacity of beneficiary communities should be undertaken prior to the commencement of a housing project and that this should inform the mode of participation pursued. Where it is apparent that there is a weak tradition of mobilization among potential housing beneficiaries, more direct involvement of the municipality is called for in communicating the principles guiding the selection process, the type of housing to be constructed, and the time-frames for completion of a project. Regular meetings with beneficiaries should also assist in developing some form of collective identity which could ultimately lead to the election of a representative leadership.

\section{Acknowledgements}

We would like to express our appreciation to the Department of Local Government and Housing of the Provincial Government of the Western Cape for permission to make use of certain information in this paper and to the Flemish Inter-University Council (VLIR) for part funding of the research undertaken. 


\section{Notes}

1. Some 6000 protests were officially recorded during the 2004/5 financial year and an estimated 15 protests were being held per day somewhere in South Africa during 2007 (Delaney, 2007).

2. Research for this article was conducted over a five-month period from November 2009 to March 2010. Based on a qualitative method, key informant and focus group interviews were conducted in each of the ten projects studied. Those interviewed included community members, beneficiary committee members, local government councillors and relevant municipal officials and project developers. In total, some 60 people were interviewed. A number of interviews, particular those involving beneficiaries, were granted on condition of anonymity.

3. Municipalities frequently contract out the actual construction of housing to private companies, thus adding a further complicating dimension to community participation. This is because housing developers are driven by the imperatives of time and profit and frequently pay lip service to the need for community participation.

4. Interview, Cupido Jacobs, Project Manager, Project 59, Drakenstein, 2 March 2010; focus group interview, beneficiary committee representatives, Drakenstein, 9 March 2010.

5. Interview, Councillor Teresa Bottoman, Kuyasa, Khayelitsha, 12 February 2010.

6. Interview, Quintus Wellman, Project Coordinator, Bardale, 17 February, 2010.

7. Interview, Mark Le Fleur, Chairperson Belhar/Pentech Housing Project Steering Committee, 10 March 2010, Belhar.

8. Interview, Edwin Herandien, Pacaltsdorp Project Co-ordinator, George, 30 November 2009.

9. Focus group interview, Project 59, Drakenstein, 9 March 2010.

10. Focus group interview, beneficiary committee members and CLO, Project 59, Drakenstein, 9 March 2010.

11. The reasons for the delays varied but included problems associated with potential environmental impact, contested land ownership, planning approval and inadequate financial resources among others.

12. Focus group interview, beneficiary committee representatives, Project 59, Drakenstein, 9 March 2010.

13. Interview, Project developer, Pacaltsdorp, George, 29 November 2009.

14. Of South Africa's 11 official languages, Afrikaans and Xhosa predominate among poor households in the Province of the Western Cape.

15. Interview, Project developer, Pacaltsdorp, George, 29 November 2009. 


\section{References}

Bénit C (2002) The rise or fall of the 'community'? Post-apartheid housing policy in Diepsloot, Johannesburg. Urban Forum 13(2): 47-66.

Burkey S (1993) People First: A Guide to Self-reliant, Participatory Rural Development. London: Zed Books.

Chambers R (1995) Paradigm shifts and the practice of participatory research and development. In: Nelson $\mathrm{N}$ and Wright S (eds) Power and Participatory Development. London: Intermediate Technology Publications, pp. 30-42.

Cleaver F (1999) Paradoxes of participation: Questioning participatory approaches to development. Journal of Development Studies 11: 597-612.

Cleaver F (2001) Institutions, agency and the limitations of participatory approaches to development. In: Cooke B and Kothari U (eds) Participation: The New Tyranny? London: Zed Books, pp. 36-55.

Cooke B (2003) A new continuity with colonial administration: Participation in development management. Third World Quarterly 24(1): 47-61.

Cooke B and Kothari U (eds) (2001) Participation: The New Tyranny? London: Zed Books. Cornwall A and Gaventa J (2001) From users and choosers to makers and shapers: Repositioning participation in social policy. Working Paper 127. Brighton: Institute of Development Studies.

da Cunha P and Pena M (1997) The limits and merits of participation. World Bank Policy Research Working Paper, 1838.

Delaney D (2007) Amandla! Protest in the New South Africa. Freedom of Expression Institute. Available at: http://www.fxi.org.za/content/view/83/ (accessed 22 January 2009)

Department of Constitutional Development and Provincial Affairs (1998) The White Paper on Local Government (Pretoria). Available at: http://mfma.treasury.gov.za/MFMA/ Guidelines/whitepaper.pdf (accesssed 14 May 2010).

Department of Housing (1994) A New Housing Policy and Strategy for South Africa (Pretoria). Available at: http://www.info.gov.za/whitepapers/1994/housing.htm (accessed 14 May 2010).

Department of Human Settlements (2009) National Housing Code. Available at: http://www.dhs.gov.za/Content/The\%20Housing\%20Code\%202009/index.ht m (accessed 14 May 2010).

Department of Public Service and Administration (1997) The White Paper on Transforming Public Service Delivery (Pretoria).

Emmet T (2000) Beyond community participation? Alternative routes to civil engagement and development in South Africa. Development Southern Africa 17(4): 501-518.

Gaventa J (2004) Towards participatory governance: Assessing the transformative possibilities. In: Hickey S and Mohan G (eds) Participation from Tyranny to Participation. London: Zed Books, pp. 25-41.

Goebbel A (1998) Process, perception and power: Notes from 'participatory' research in a Zimbabwean resettlement area. Development and Change 29: $277-305$. 
Hickey S and Mohan G (2004) Towards participation as transformation: Critical themes and challenges. In: Hickey S and Mohan G (eds) Participation from Tyranny to Transformation. London: Zed Books, pp. 3-24.

Jennings R (2000) Participatory development as new paradigm: The transition of development professionalism. Paper prepared for the 'Community Based Reintegration and Rehabilitation in Post-conflict Settings', Conference, Washington, DC, October. Available at: http://www.usaid.gov/our_work/crosscutting_programs/transition_initiatives/pubs/ptdv10oo.pdf.

Kapoor I (2002) The devil's in the theory: A critical assessment of Robert Chambers' work on participatory development. Third World Quarterly 23(1): 101-117.

Lavigne Delville P, Sellamna N and Mathieu M (2005) Living up to ambitions: For a more rigorous practice of participatory appraisals and inquiries. In: Neef A (ed.) Participatory Approaches for Sustainable Land Use in Southeast Asia. Bangkok: White Lotus Press, pp. 35-72.

Lemanski C (2008) Houses without community: Problems of community (in)capacity in Cape Town, South Africa. Environment and Urbanization 20: 393-410.

Manor J (2004) User committees: A potentially damaging second wave of decentralisation? European Journal of Development Research 16(1): 194-213.

Mehta L, Thompson L and Nleya N (2010) Water rights and state management in India and South Africa. In: Thompson L and Tapscott C (eds) Citizens and Social Movements: Perspectives from the Global South? London: Zed Press.

OECD (1997) Evaluation of Programs Promoting Participatory Development and Good Governance, Synthesis Report of the DAC Expert Group On Aid Evaluation. Paris: OECD. Available at: http://www.oecd.org/dataoecd/39/44/35019452.pdf (accessed 17 March 2010).

Oldfield S (2000) The centrality of community capacity in state-low income housing provision in Cape Town, South Africa. International Journal of Urban and Regional Research 24(4): 859-872.

Platteau J and Abraham A (2002) Participatory development in the presence of endogenous community imperfections. Journal of Development Studies 39(2): 104-136.

Republic of South Africa (1996) The Constitution of the Republic of South Africa Act 108 of 1996. Pretoria: Typeface Media.

Republic of South Africa (1997) National Housing Act 107 of 1997. Cape Town, Government Gazette 18521.

Republic of South Africa (2008) Social Housing of Act 16 of 20o8. Cape Town, Government Gazette 25721.

Tapscott C (2000) Inter-governmental relations in South Africa: The challenge of coperative government. Public Administration and Development 20(2): 119128.

Thompson L and Nleya N (2010) Passitivity or protest? Understanding the dimensions of mobilisation on rights to services in Khayelitsha, Western Cape. In: Von Lieres B and Coelho VS (eds) Mobilising for Democracy? London: Zed Books, pp. 223-242. 
Thompson L and Tapscott C (2010) Mobilisation and social movements in the south: The challenges of inclusive governance. In: Thompson L and Tapscott C (eds) Citizens and Social Movements: Perspectives from the Global South. London: Zed Books, pp. 1-12.

UNDP (1995) Human Development Report. New York: Oxford University Press.

World Bank (1998) The World Bank Participation Sourcebook. New York. Available at: http://www.worldbank.org/wbi/sourcebook/sbhome.htm. 